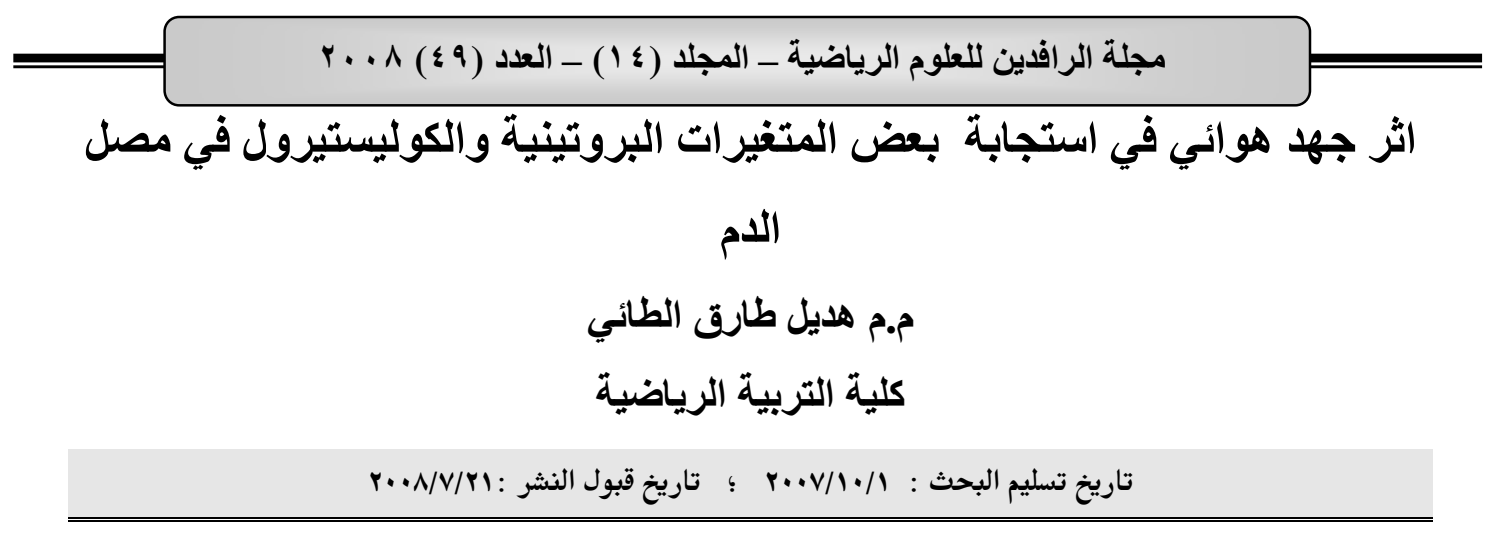

$$
\begin{aligned}
& \text { الملخص } \\
& \text { درس البحث اثر جهد هوائي في استجابة بعض المتغيرات البروتينة والكوليستيرول في }
\end{aligned}
$$

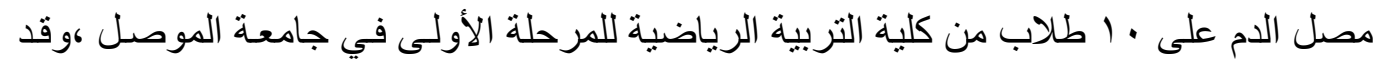

$$
\begin{aligned}
& \text { تضمنت إجر اءات البحث إجر اء اختبار قبلي لمتغيرات البحث واختبار بعدي لركضة ... بام }
\end{aligned}
$$

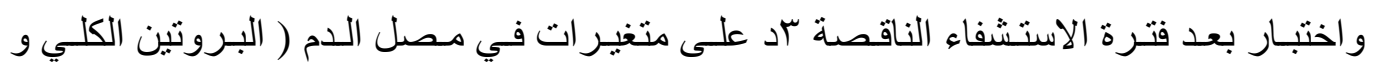

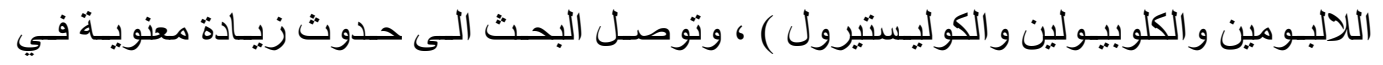

$$
\begin{aligned}
& \text { اللالبومين و الكوليستيرول في اختبار بعد الجهد مقارنة مع اختبار قبل الجهد مـا عدا الكلوبيولين }
\end{aligned}
$$

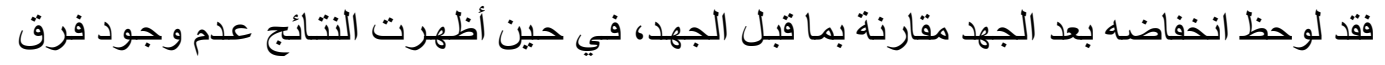

$$
\begin{aligned}
& \text { معنوي في اختبار بعد الجهد مقارنة مـع اختبار بعد فترة الاستشفاء، وجود فرق معنوي في }
\end{aligned}
$$

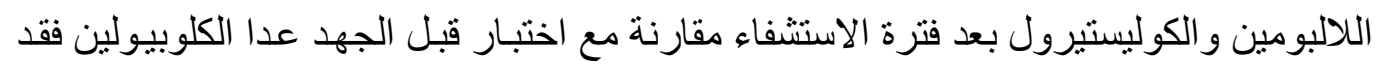

$$
\begin{aligned}
& \text { لوحظ انخفاضه بعد فترة الاستشفاء. }
\end{aligned}
$$

\section{Abstract \\ Effect of Aerobic stress on responding some protein and cholesterol variables in blood serum}

\author{
Hadeel T. Younis \\ University of Mosul /College of Physical \\ Education
}

The research studied the effect of aerobic stress in responding some variables of proteins and cholesterol in blood serum on ten students from Physical Education College /first stage/University of Mosul. Procedures of the present research included pre-test and post-test for 
(3000m) running and at recovery period (3 minutes)After exercise on some variables in blood serum (total protein, albumin, globulin and cholesterol). The results of the research showed a significant increase in albumin and cholesterol in post-aerobic test in comparing with preaerobic test except globulin which decreased in post-aerobic test. There was a significant difference in post-aerobic test in comparing with postrecovery test. Also, a significant difference occurred in albumin and cholesterol in post-recovery test in comparing with pre-aerobic test except globulin which was low in post-recovery.

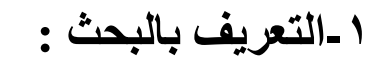

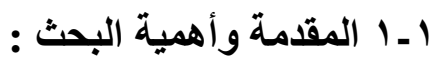

تهتم الدول المتقدمة والدربون اهتماما بالغآ في فسلجة التدريب نظر اللدور الذي تلعبه في

تتمية وتطوير اللياقة البدنية و الاستجابات الوظيفية للرياضيين بوصفها أسلوبا علميا تخصصيا في لطي التطـوير ، لـذا أولت هذه الدول و المـدربين رعايـة خاصـة وكييـرة في تحديث وتـوفير كافـة الإمكانيات المادية و البشرية لعلمائها للنهوض بالإنجاز الرياضي وصحة الفرد . .

ويمكن الاستفادة من معلومـات فيسولوجيا التدريب الرياضي في تطوير اللياقة البدنية

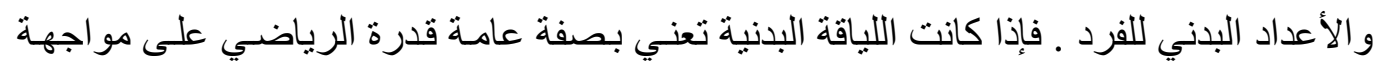

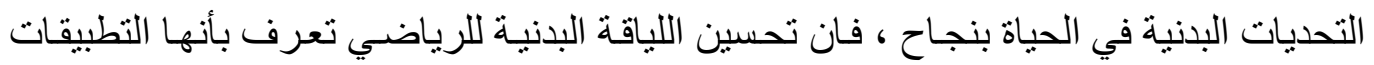
الأساسية لفسيولوجيا الرياضـة لتحسين استجابة وتكيف الإنسان لتحديات الحيـاة والتدريبات

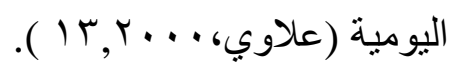

يحصل الجسم من البيئة على المو اد الغذائية المختلفة ، وهذه المو اد غنية بمصادر الطاقة في شكلها الكيميائي "الكاربو هيدرات والدهون و البروتينات"وتتحول هذه المواد من خـلال الهضم الى مو اد بسيطة في الدورة الدموية كالأحماض الأمينية و الأحماض الدهنية الكلوكوز لكي يقور لئون الجسم بتخزينها أو استهلاكها كمصدر للطاقـة اللازمـة ،يستخدمها في بنـاء وتحديث الخلايـا

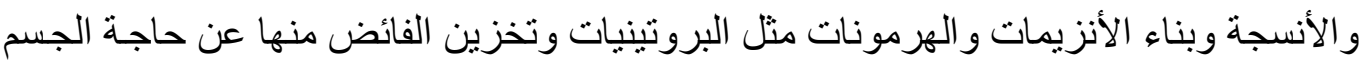

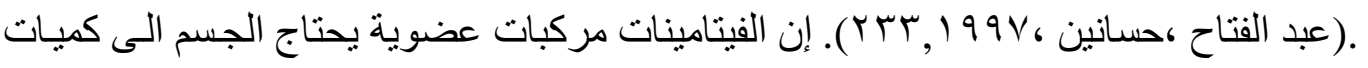
صغيرة منه لعمليات الجسم الايضية و لايمكن تصنيعه في خلايا الجسم وتختلف هذه المنطلبات لدرجة كبيرة حسب العو امل المختلفة ،مثل حجم الجسم وسرعة النمو ومقدار الرياضـة والحمل Pregnany

إذ يكتسب البحث أهميته من خلال فهم آلية عمل هذه بعض المتغيرات للبروتينات و الدهون

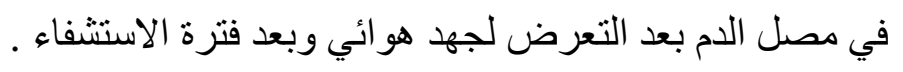


إن الاستجابة في أعضاء جسم الرياضي وأجهزته تعد أحد العوامل المؤثرة في مستوى

الإنجـاز ـ ومسن الاسـتجابات المهمـة التـي تصـاحب الجهد البدني هـو اسـتجابة جهـاز الدوران وخصوصاً الدم الذي يلعب دوراً مهماً في نقل الأوكسجين والمو اد النافعة إلى أجزاء الجسم العامة المساهمة في الجهد الرياضي (كعضلات الاطر اف السفلى في الاركاض ) و التخلص من نواتج العمل الأيضي في تللك الأعضاء.

إن مشكلة البحث تكمن في التعرف على آلية عمل بعض البروتينات وكوليستيرول الدم

بعد الجهد هو ائي الذي يمتـاز بالشّة المتوسطة وفترة دو ام متوسطة وينتهي بالثندة العالية أي الدخول الى العتبة الفارقة اللاهو ائية وكذللك التعرف ثم متابعة التغير ات على عمل هذه الآلية لهذه المتغير ات في فترة مـا بعد الاستشفاء بعد الجهد الهو ائي فضلاً عن التعرف على القيم لهذه المتغير ات في ظروف الر احة لغرض المقارنة .

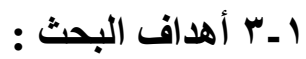
ا. التعرف على الفروقات في استجابة البروتين الكلي والألبومين و الكلوبيولين والكوليستيرول بين الاختبار القبلي(الراحة) و البعدي . ץ.التعرف على الفروقات في استجابة البروتين الكلي و الألبومين و الكلوبيولين و الكوليستيرول بين الاختبار البعدي واختبار بعد الاستثفاء ـ r.التعرف على الفروقات في استجابة البروتين الكلي و الألبومين و الكلوبيولين و الكوليستيرول بين الاختبار القبلي(الراحة) و اختبار بعد الاستشفاء .

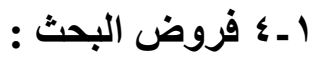
ا. وجود فروقات ذات دلالة معنوية في البروتين الكلي والألبومين و الكلوبيولين والكوليستيرول بين الاختبار القبلي(الراحة) و البعدي . r. وجـود فروقـات ذات دلالـة معنويـة في اسـتجابة البـروتين الكلـي والألبـومين والكلوبيـولين و الكوليستيرول بين الاختبار البعدي واختبار بعد الاستشفاء . "م. وجـود فروقـات ذات دلالـة معنويـة في اسـتجابة البـروتين الكلـي و الألبـومين و الكلوبيـولين والكوليستيرول بين الاختبار القبلي(الراحة) واختبار بعد الاستشفاء .

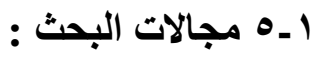
ا ـ المجال البشري : طلبة كلية التربية الرياضية / المرحلة الثالثة .

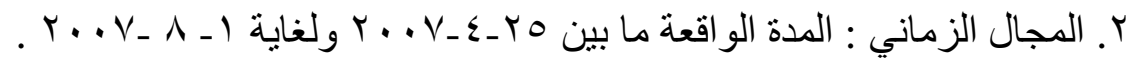
بـ. المجال المكاني : ملعب جامعة الموصل / كلية التربية الرياضية ، مختبر كلية العلوم . 


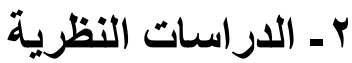

The Aerobic System النظام الهوائي

يعد النظام الهو ائي من أنظمة إنتاج الطاقة المستخدمة في الفعاليات ذات الثدة المعتدلة

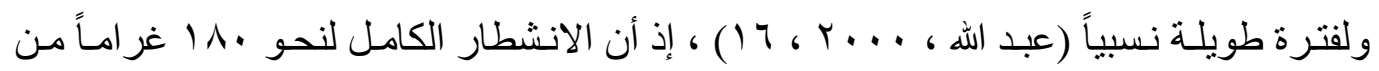

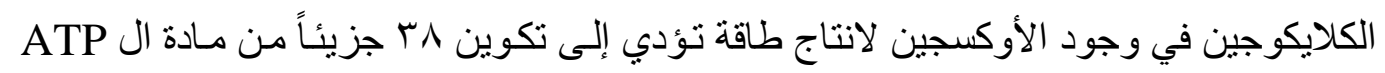

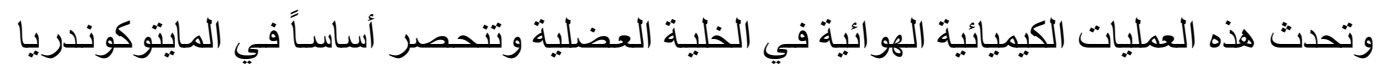
Mitochondria

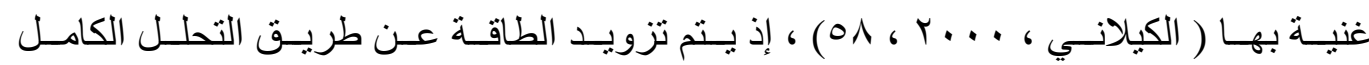

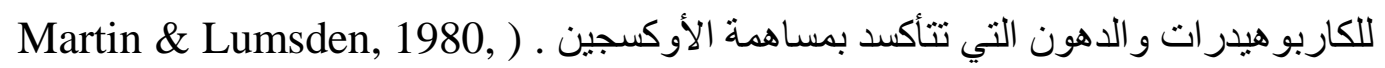
166) و الطاقة المتولدة في هذا النظام هي الضعف ــ مـ مرة تقريبا من تللك الطاقة المتو افرة مجتمعة في كلا النظامين اللاهو ائيين و عليه فهو النظام الأكثر كفاءة من النظامين السابقين بمـا

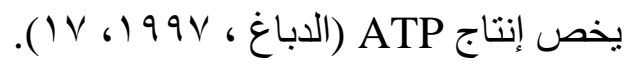

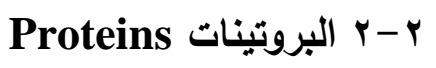

تعدُ البروتينـات أكثر الجزيئات الخلويـة انتشارا إذ تأتي في المرتبـة الأولى مـن بين

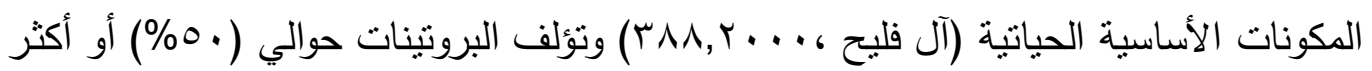

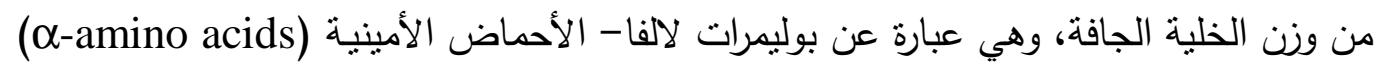

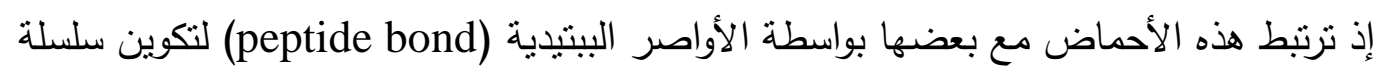

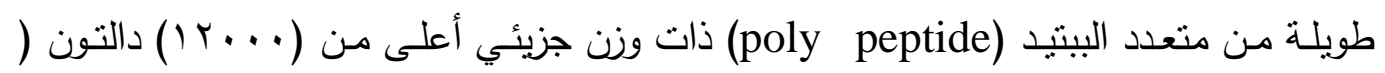
.(Lehninger, 1982,278) ( Maiti, 1995,102

\section{Albumin r ب الألبومين}

يعدُ الألبومين من المركبات الأكثر حصة لمجموع البروتين في الدم والذي يشكل حوالي من ماني

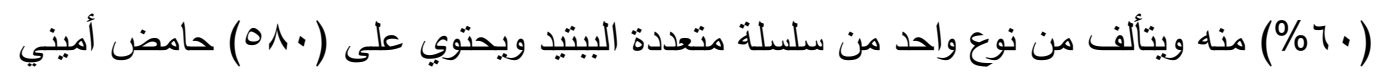

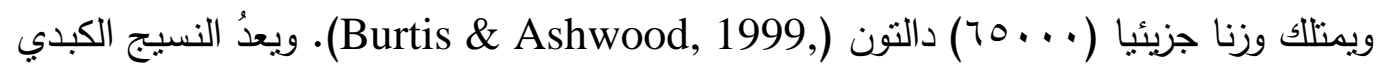

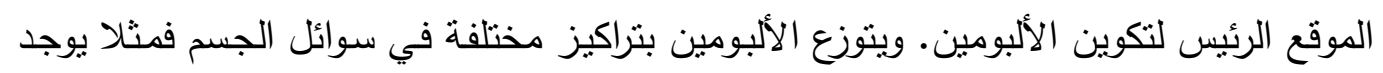

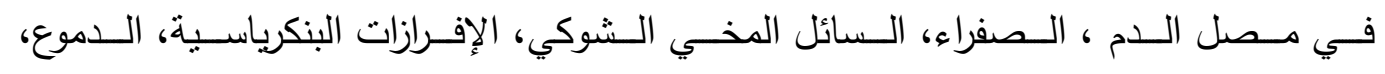
.( Murray et al., 1999 ,473)(Danishefsky, 1980,232) 
ب ـ ـ الكلوبيولين

يكون على أنواع عدة الفـا ـ كلوبيولين ويقوم بنقل السترويدات و الدهون الفسفورية ،

الفاب ـ كلوبيولين يقوم بنقل الدهون و الهيموكلوبين المتكسر من كريات الدم الحمر اء كما يقوم بنقل النحاس ، بيتـاـ كلوبيولين يقوم بنقل الحديد أمـا بالنسبة الى كامـا كلوبيولين فيعد مـن الأجسام المضادة ويقوم بوظائف دفاعية ) (Rose et al., 1986, 126) .

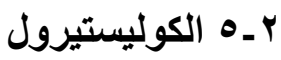

يوجد الكوليستيرول في الطعام يمتص يوميا من السبيل المعدي المعوي الذي يسمى

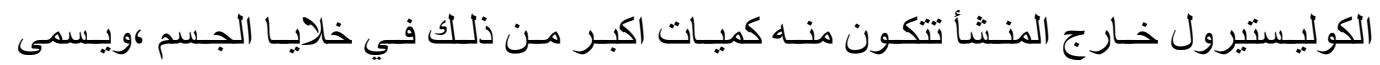
الكوليستيرول داخلي المنشأ وفي الوقع يتكون كل الكوليستيرول داخلي المنشأ الذي يدور في البروتينات الثحمية للبلازما في الكبد ،ولكن كل خلايـا الجسم الأخرى تكون على الأقل بعض

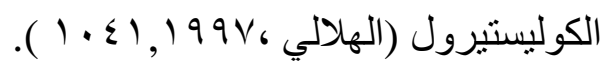
ويمكن للكوليسترول أن يفرز الى بلازمـا الدم من الخلايـا الكبديـة في البروتين الدهني و أطسى الكثافة جدآ ،أو يقوم الجسم بـإفر ازه بو اسطة الصفر اء على شكل كوليستيرول أو بعد تحويله الى حو امض صفر اوية التي يتم إعادة امتصاصها جزئيا وتعود الى الكبد بواسطة الدورة الدمويـة للكبد حيث إن حدوث أي خلل يـؤدي الحى زيـادة تحـول الكوليستيرول الى حـوامض صفر اوية وقلة في مخازن الكوليستيرول الموجود في الكبد وزيادة في مستقبلات البروتين الدهني و أطى الكثافة(Zilva et al. , 1988, 231).

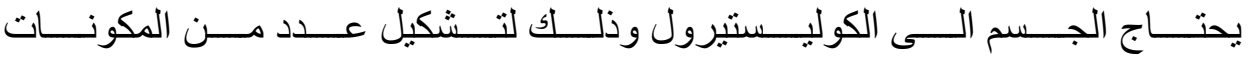

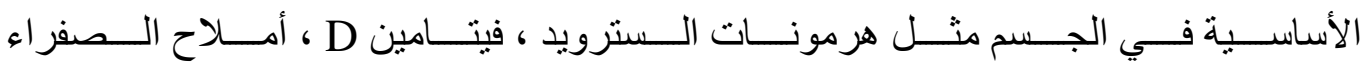
. (Guthric \& Picciano, 1995,365)( King, 2004,171) "إجراعات البحث

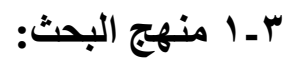
استخدم الباحث المنهج الوصفي لملاعمته مع طبيعة البحث

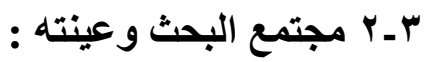
تألف مجتمع البحث من طلاب السنة الثالثة في كليـة التربية الرياضية بجامعة الموصل

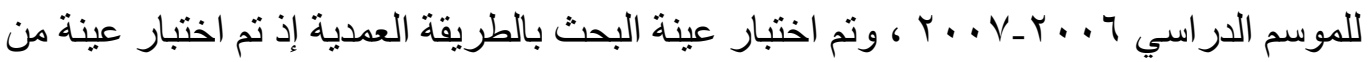
الطلبة الذين لايهم قدرة على أداء الجهد البدني خلال اختيار ( T Y ) طالباً من مجتمع البحث الكلي البالغ عددهم (T • Y) طالباً . بعد أن تم الحصول على نتائج اختبار اتهم في عدو المسافات الطويلة من مدرس اللياقة البدنية. 


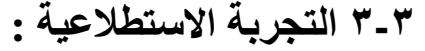

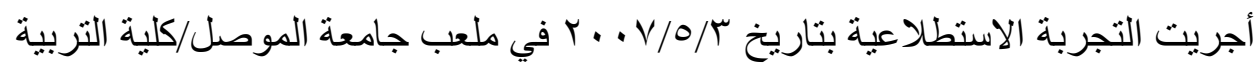
الرياضية على طالبين من عينة البحث في الساعة ـالصباحاً وتم استبعادهم من عينة البحث

$$
\text { وكان هدف التجربة الاستطلاعية هي : }
$$

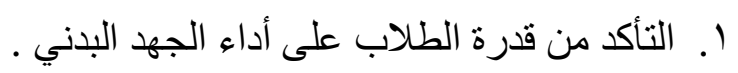

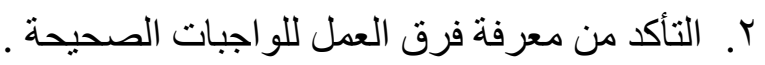

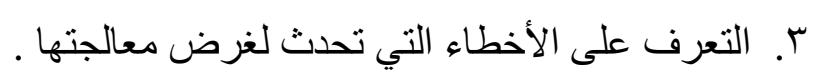

وفي ضوء هذا العمل تم تحديد إجراءات عمل التجربة الرئيسية .

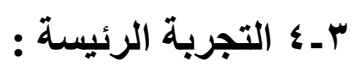

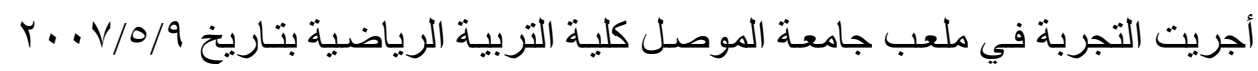

بمصاحبة فريق العمل والطلاب في الساعة التاسعة صباحاً وتمت تهيئة المستلزمات و الأجهزة

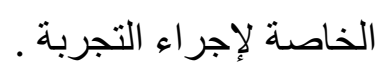

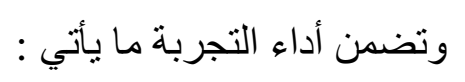

أداء الطـلاب عمليـة الإحمـاء لمدة (10 ) دقيقة يتم خلالها أداء هرولـة بطيئة مـع أداء مجمو عة من التمرينات السويدية ، وقد روعي أن تكون عملية الإحماء موحدة من حيث تسلسل

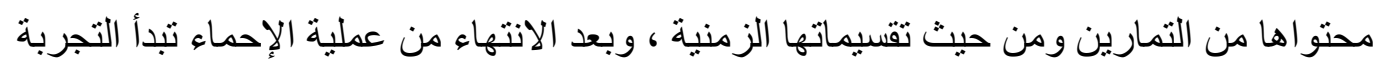

$$
\text { على أن يحافظ بقية الطلبة على إحمائهم لحين بدئهم التجربة . }
$$

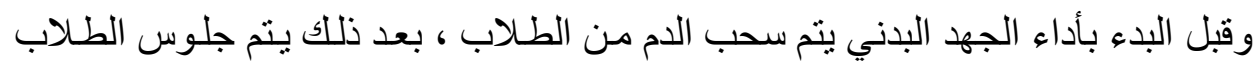

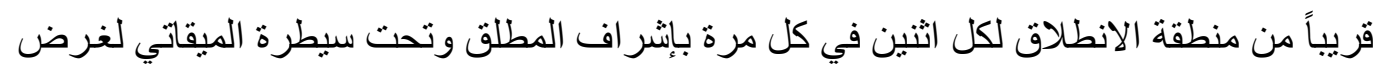

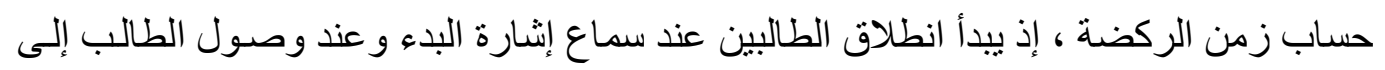

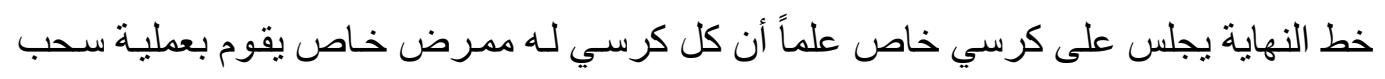

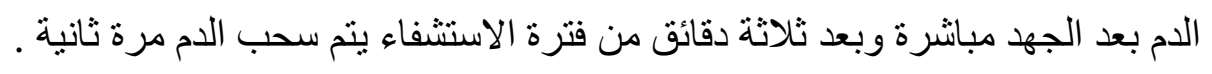

$$
\text { بـ الو الوسائل الإحصائية }
$$

استخدم الباحث الوسائل الإحصائية الآتية : الإسنائ

$$
\text { الوسط الحسابي }
$$

$$
\text { الانحر اف المعياري }
$$

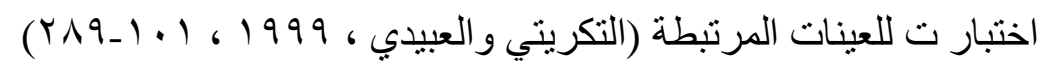




\section{ع ـ عرض التتائج ومناقشثتها

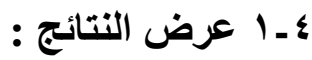

ع ـ ا ـ ا عرض نتائج البروتين الكلي اللالبومين والكوليستيرول والكلوبيولين بين الاختبار القبلي(الراحة) واختبار بعد الجهد مباشرة.

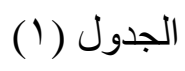

\begin{tabular}{|c|c|c|c|c|c|}
\hline \multirow{2}{*}{ المحتسبة } & \multicolumn{2}{|c|}{ بعد الجهد مباشرة } & \multicolumn{2}{|c|}{ قبل الجهد } & \\
\hline & $\varepsilon \pm$ & س- & $\varepsilon \pm$ & س- & رات \\
\hline 1.0 & 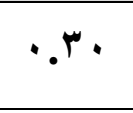 & V.rq & $\because r V$ & $7.9 r$ & غرام /الاسيبي ليثي الكي \\
\hline$* \vee . \vee$. & $.0 \leq$ & $7 . r 9$ & $\because \Lambda \varepsilon$ & $\varepsilon . r$ & غز ام /الاسبي ليتر \\
\hline$* r_{.} \leq 0$ & $r 7 . \leqslant r$ & 171.199 & $r V . \wedge \varepsilon$ & $1 \% \wedge .99$ & غرام /الدسي ليستيرول ليتر \\
\hline$* \varepsilon, Y Y$ & $\because \Lambda V$ & 1.11 & .71 & $Y . \wedge q$ & غرام /الاسيي ليتر \\
\hline
\end{tabular}

* معنوي عند نسبة خطأ ه... أمام درجة حرية 9 ، قيمة (ت) الجدولية 1.83.

ـ ـ ا ـ ع عرض نتائج البروتين الكلي اللالبومين والكوليستيرول والكلوبيولين بين الاختبارين البعدي وبعد فترة الاستثفاء.

الجدول(r)

\begin{tabular}{|c|c|c|c|c|c|}
\hline \multirow{2}{*}{ |المحتسبة } & \multicolumn{2}{|c|}{ بعد فترة الاستشفاء } & \multicolumn{2}{|c|}{ بعد الجهد مباشرة } & \\
\hline & $\varepsilon \pm$ & س س & $\varepsilon \pm$ & س - س & 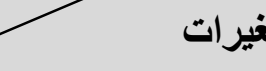 \\
\hline $.9 r$ &. .21 & 7.91 &.$r$. & $v . r q$ & غرام /الاستي اليلير \\
\hline. .11 &.$\wedge 0$ & $7 . \varepsilon r$ & $.0 \leq$ & $7 . r q$ & غرام /الألبي ليتر \\
\hline 1.11 & $r \Lambda_{.} \cdot \varepsilon$ & $I V \varepsilon . Y$. & $r q . \varepsilon r$ & 171.89 & غرام /الاسيسي ليتر \\
\hline.$r \cdot$ & $1.1 \%$ & 1.1 &.$\wedge V$ & 1.11 & غرام /الاسبي ليتر \\
\hline
\end{tabular}

* معنوي عند نسبة خطأ ه ... أمام درجة حرية 9 ، قيمة (ت) الجدولية 1.83. 
ـ ـ ـ ـ عرض نتائج البروتين الكلي اللالبومين والكوليستيرول والكلوبيولين بين الاختبار القبلي(الراحة) وبعد اختبار فترة الاستثفاء.

(r) الجدول)

\begin{tabular}{|c|c|c|c|c|c|}
\hline \multirow{2}{*}{ المحتسبة } & \multicolumn{2}{|c|}{ بعد فترة الاستثفاء } & \multicolumn{2}{|c|}{ قبل الجها } & \\
\hline & $\varepsilon \pm$ & س- س & $\varepsilon \pm$ & س- س & ل يرات \\
\hline .14 & $\cdot v 1$ & 7.91 & $\cdot r v$ & $7.9 r$ & غرام /الاسبي ليتير \\
\hline$* \eta . \vee r$ & $\bullet \wedge \bullet$ & $7 . \leqslant r$ & $\cdot . \wedge \varepsilon$ & $\varepsilon . \cdot r$ & غرام /الاسلي ليتر \\
\hline$* r .1 V$ & $r \Lambda_{\cdot} \cdot \varepsilon$ & $I V \leqslant . r$. & YV.As & $14 \Lambda_{.99}$ & غرام/الاسستيروليتر \\
\hline$* \varepsilon .74$ & $1.1 r$ & 1.91 & $\cdot .71$ & r.^q & غرام /الاسبي ليتر \\
\hline
\end{tabular}

* معنوي عند نسبة خطأ ه ... أمام درجة حرية 9 ، قيمة (ت) الجدولية 1.83.

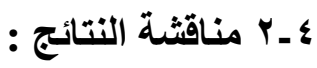

ـ ـ ؟ ـ ا مناقثة نتائج البروتين الكلي اللالبومين والكوليستيرول والكلوبيولين بين الاختبار القبلي(الراحة) واختبار بعد الجها مباشرة :

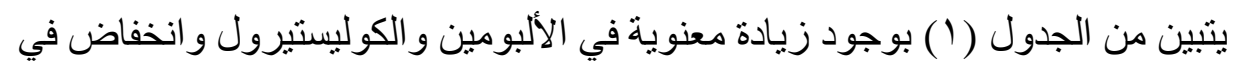
الكلوبيولين بعد الجهد مباثرة ومن الوظائف الحياتية المهمة للالكبومين نقل عدد من مكونات الدم

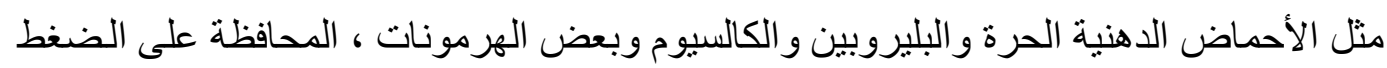

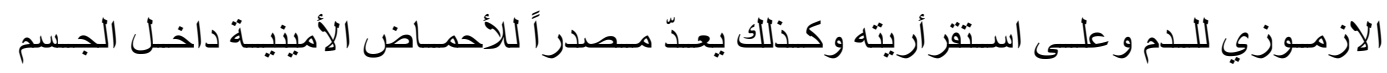

.(Bishop et al., 1985, 116)

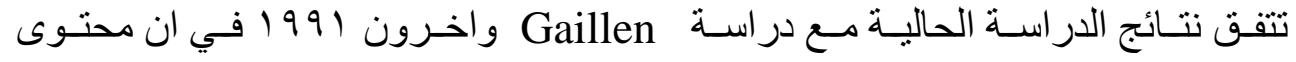

الالبو مين في البلازما يزداد مباثرة بعد جهد مرتفع وييقى مرتفعا في فترة استعادة الاستشفاء .

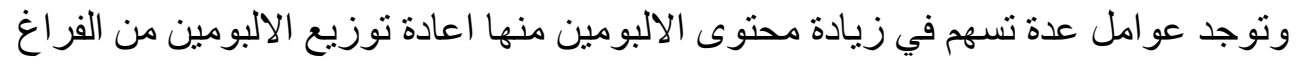
بين الانسجة interstitial الى الفراغ داخل انسجة الاوعية الدموية intrarasnla

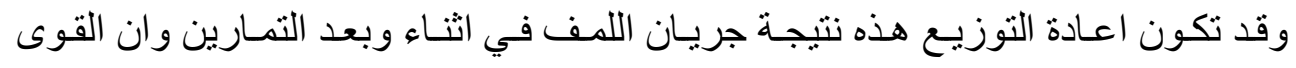

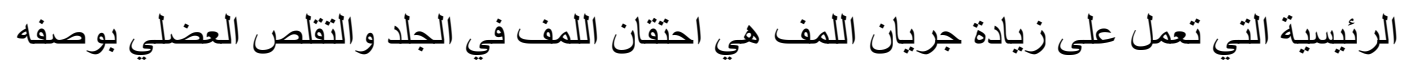

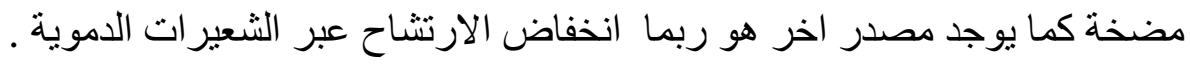


توجد عوامل اخرى توثر في معدل تصنيع الالبومين منها المستويات الموثرة في الدم لكل من الكورتيزول والثيرويد و الكلوكاكون والبينفرين وكذلك الوضع الغذائي.

(Gaillen CM,et al ,1994-1920,1991)

حيث ينفصل الكلوبيولين الى أربعة أجزاء مهمـة هي وا

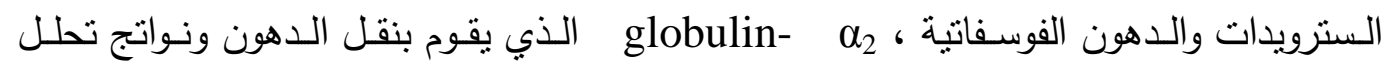
الهيموكلوبين كما يقوم بنقل النحاس ، وlobulin- الذي شمل بيتا - لايبوبروتين والترانسفريز

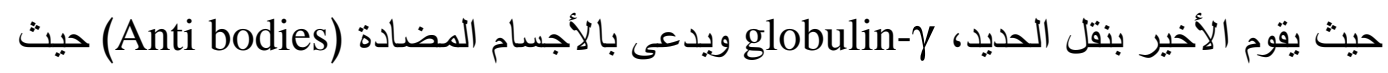
يقوم بوظائف دفاعية نتيجة احتوائه على أجسام مضادة مختلفة التي تسمى أيضا( البروتينات المناعية ) (Immunoglobulin (Ig) واهم أنواعه(IgG, IgA, IgM, IgD, IgE) (Rose et al., 1986, 126)

وتتفق هذه النتيجة مع ما جاء به النعيمي بان المناعة تقل في الجهد الرياضي ذو المسافات

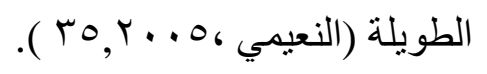

تعتبر الكاربو هيدر ات والدهون هي وقود الطاقة بالجسم ، وبـالر غم من ذلك فـان بعض

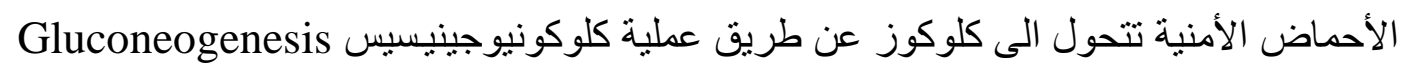

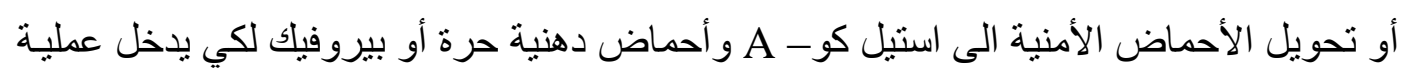

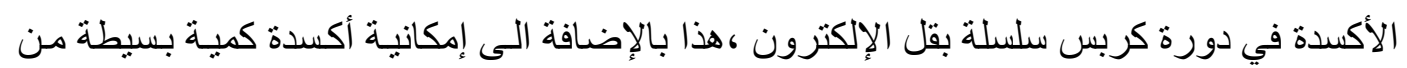

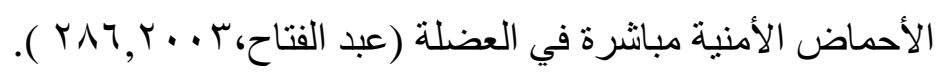

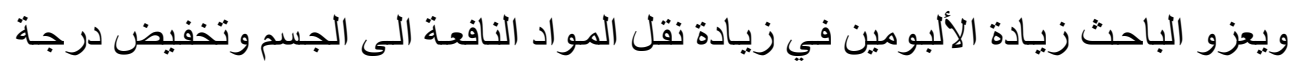

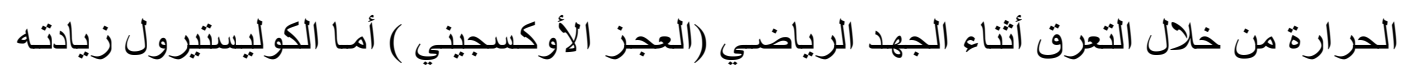

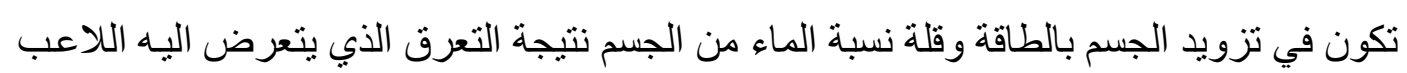

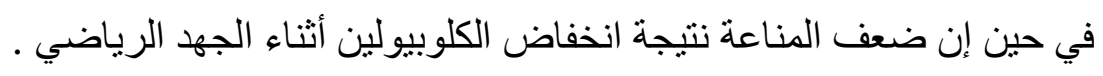
اما انخفاض الكلوبيولين فيعتقد الباحث ان السبب في ذلك يعود الى انشغال خلايـا الكبد بتلبيـة حاجـة الجسم الطارئـة في ظرف الجهد الى الالبومين وتحويل الخلايـا الكبديـة الى انتـاج الالبو مين بشكل رئيسي .فضلاعن ان الكلوبيولين بمكوناته المختافة لاتكاد تساهم في تلبية الحاجـة

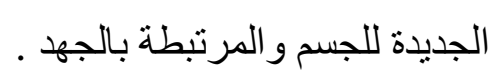

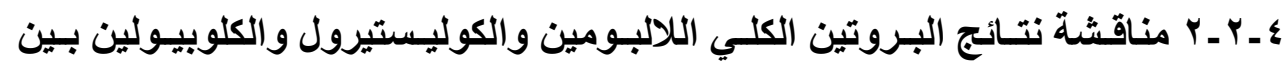
الاختبار القبلي(الراحة) وبعد اختبار فترة الاستشفاء :

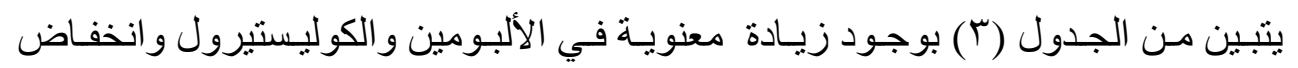

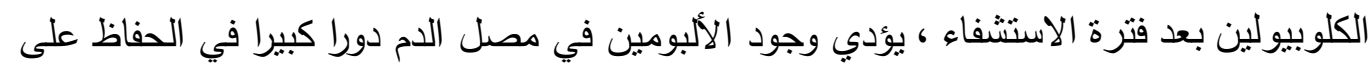

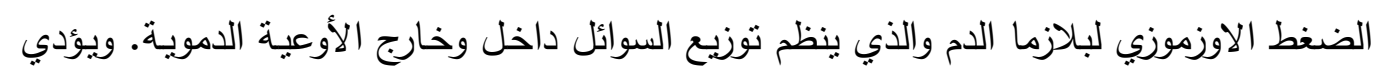


الألبومين دورا مهما في عملية نقل عدة مركبات مثل الأحماض الدهنية ذات السلاسل الطويلة،

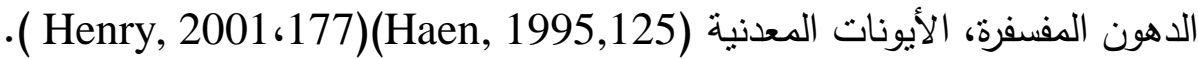
في دراسة Kei Nagashima ييقى تركيز الالبومين في البلازما مرتفعا من استعادة

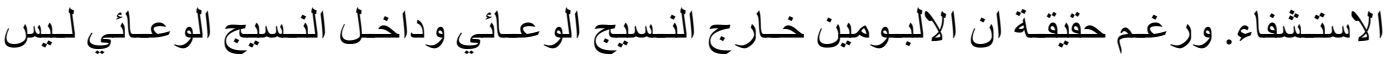
بالضرورة يتغير الى شكل ميواز الا ان الالبومين البلازما يجب ان ينتقل بسهولة الى الفراغ بين الفين النسيج الكبدي عبر الجدران المثقبـة في المنحنيـات الكبديـة ـ ولهذا السبب فـان التركيز العـالي لالبومين البلازما بعد جهد شديد قد يغير من تركيز الالبومين في الفراغ بين النسيج الكبدي باتجاه قد يضعف عملية تصنيع الالبومين . يرتبط التمرين المجهد بزيادة افراز مجمو عة من هورمونات الجهد مثل امينات الكانيكول و الكورتيزول و الكلوكاكون ـ ان ارتفاع مستويات هورمونات الجهد اثثاء الجهد البدني ربمـا يحفز

(Kei Nagashima,2000, 41-46). عملية تصنيع الالبومين عندما ينقص مخزون الجسم من السكريات الى اقل من السوي ،يمكن أن تشكل كميات

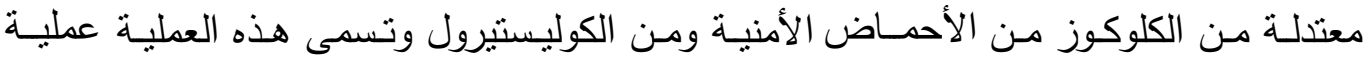

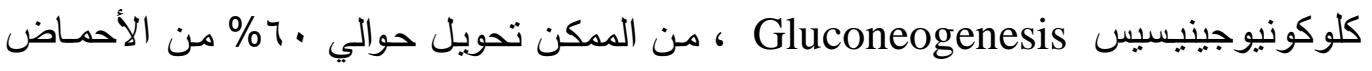
الأمنية في بروتينات البلازما الى سكريات ، تترك الحوامض الدهنية الخلايا الدهنية فأنها تتأين

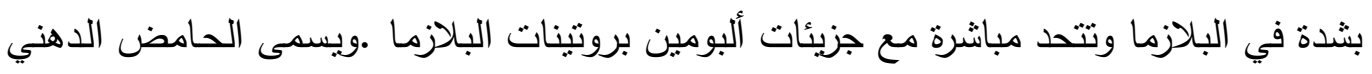

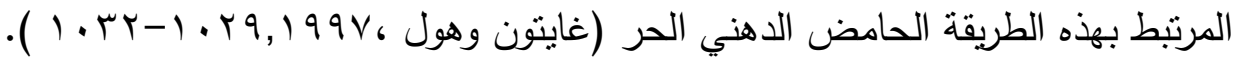

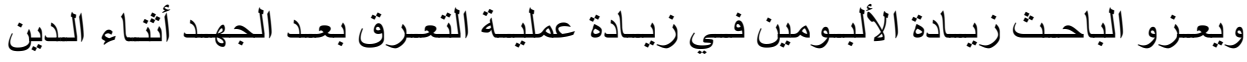

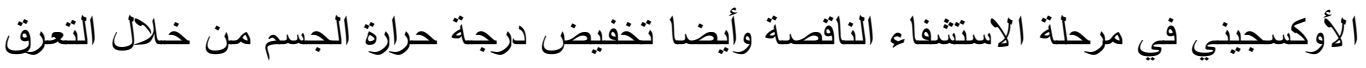

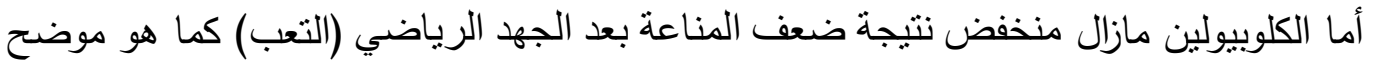
سابقا.

أما الكوليستيرول يدخل في مرحلة تعويض الطاقة المصرفة والتحلل من اجل تزويد الجسم بالأوكسجين الى زيادة نسبة التعرق التي تحدث اثناء الجها وبعد الجهد في فترة استعادة الاستشفاء و هذا ما جاء بـه في معظم الدر اسـات المجر اة على أثخاص ذوي مستوى كوليستيرول فان هذا المتغير لا يحدث تغير معنوي بالجهد إذ مقارنه مع مستوى البلازمـا (معدل حجم البلازمـا ). (Davis PC et al ,1992, 914-919) 


$$
\text { أظهرت نتائج البحث ما يأتي : }
$$

ا. . وجود ارتفاع معنوي في مستوى اللالبومين و الكوليستيرول بعد الجهد مباشرة مقارنة مع حالة ما قبل الجهر عدا الكلوبيولين منخفض بعد الجهد. Y. لا يوجد ارتفاع أو انخفاض معنوي في جميع المتغير ات بعد فترة الاستشفاء مقارنـة مـع بعد

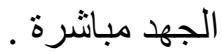

". . وجود ارتفاع معنوي في اللالبومين و الكوليستيرول بعد فترة الاستشفاء مقارنة مع حالة ما قبل

الجهد عدا الكلوبيولين منخفض بعد الجهد.

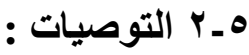

ا ـ مر اعاة المدربين و المختصين في فعاليات العدو لألعاب القوى معرفة أهمية البروتينات وما له دور أساسي في العملية التدريبية . ץ. ضـرورة أن يأخذ المدربون والمختصون بنظر الاعتبار حالة الاستشفاء وقيم عودتها إلى ع. Over load الحالة الطبيعية عند إعطاء التدريبات الرياضية في قو اعد التدريب كالتحميل الزائد والتكيف Adoption وقاعدة فوق التعويض Over compensation . r. ضرورة مر اعاة تناول الأطعمة الغذائية الغنية بالبروتين وخاصة عند اللاعبين المتعرضين إلى الثدة العالية . ء. إجر اء دراسات أخرى بنفس المتغير ات ولكن بقصر أو طول فترة الاستشفاء وشدد مختلفة و على عينات مختلفة . ๑. إجر اء بحوث على عينات ذات مستوى رياضي أفضل و عمر تدريبي آخر . المصادر

ا ـ آل فليح، خولة أحمد ( . . . ץ). "مدخل إلى الكيمياء الحياتيـة". دار الكتب للطباعـة و النشر ، مطبعة جامعة الموصل، الموصل. r. التكريتي ، وديع ياسين ، العبيدي ، محسن عبد (999 1 ) التطبيقات الإحصائية في بحوث

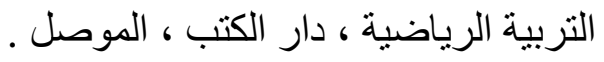
". الدباغ ، احمد عبد الغني طـه (999 ( ) ) :"التحليل الزمني و الفسلجي لـلاداءات في فعـاليتي سلاح الثيش وسيف المبارزة" ، رسالة ماجستير غير منشورة ، جامعة الموصل . ع. عبد الفتاح ، أبو العلا احمد (9191 () :"بيولوجيا الرياضية وصحة الرياضي ، دار الفكر العربي ، القاهرة . 


$$
\begin{aligned}
& \text { ๑. عبد الفتاح ، أبو العلا احمد و حسانين ،محمد صبحي (997 ( ): فسيولوجيا ومورفولوجيا } \\
& \text { الرياضي وطرق القياس للتقويم ، دار الفكر العربي ، القاهرة . }
\end{aligned}
$$

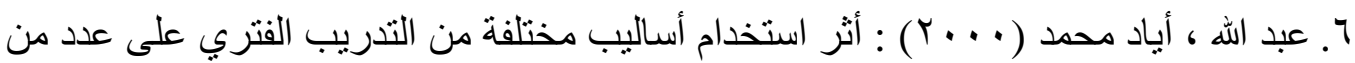

$$
\begin{aligned}
& \text { المتغير ات الوظيفيـة والإنجـاز في عدو . . ع متر " ، أطروحـة دكتور اه غير منشورة ، } \\
& \text { جامعة الموصل. }
\end{aligned}
$$

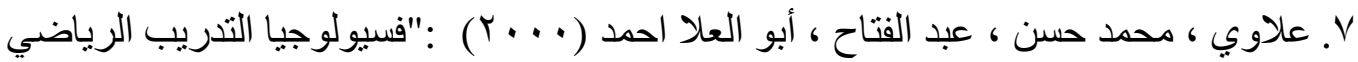

$$
\begin{aligned}
& \text { ، طب ، دار الفكر العربي ، القاهرة . }
\end{aligned}
$$

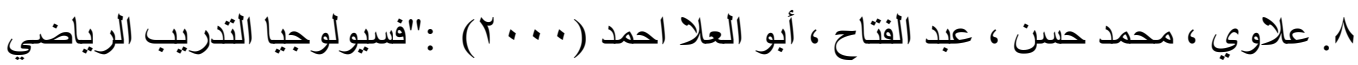

$$
\begin{aligned}
& \text { ، طب ، دار الفكر العربي ، القاهرة . }
\end{aligned}
$$

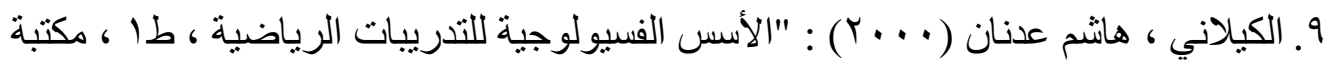

$$
\begin{aligned}
& \text { الفلاح للنشر و التوزيع ، الكويت . }
\end{aligned}
$$

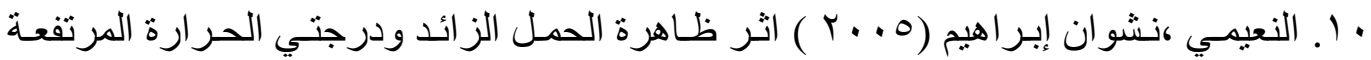

$$
\begin{aligned}
& \text { و الطبيعية في بعض متغيرات الجهاز المنـاعي ، أطروحـة دكتور اه غير منشورة ، جامعة } \\
& \text { الموصل. } \\
& \text { الصحة العالمية ، بيروت . }
\end{aligned}
$$

12.Bishop, L.; Duben, Vonlarfen J.L. and fody, G.P. (1985). "Clinical chemistry, principles, procedures and correlations". J.B. Lippincott, Company, London.

13.Danishefsky I. (1980). "Biochemistry for medical sciences". $1^{\text {st }}$ ed., Little, Brown and Company, USA.

14.Guthric, H.A. and Picciano M.F. (1995). "Human nutrition". McGraw Hill, New York.

15.Haen P.J. (1995). "Principle of Hematology". WM.C. Browns Communications Inc., USA.

16.Henry J.B. (2001). "Clinical diagnosis and management by laboratory methods". $20^{\text {th }}$ ed., W.B. Saunders company, A Harcourt Health Sciences Company, Philadelphia. 
17.King, M.W. (2004). "Medical Biochemistry". Academic Excelience,.

18.Lehninger A.L. (1982). "Biochemistry". $6^{\text {th }}$ ed., The Johns Hopkins University, School of Medicine, Worth publishers, Inc.

19.Maiti C.R.(1995). "Aconcise note on medical laboratory technology". New Central Book Agency Ltd., Calcutta.

20.Martin, C. and Lumsden, J, (1980): "Coaching on affective behavioral approach, Time Mirror Mosby, college Publishing Toronto .

21.Murray R.K., Granner D.K., Mayes P.A. and Rodwell V.W. (1999). "Harper's Biochemistry". 25 ${ }^{\text {th }}$ ed., Middle East Edition, California.

22.Rose , N. R., friedman , H. and Fehey, J. L. (1986) . “ Manual of Clinical Laboratory immunology" $3^{\text {rd }}$ ed., Mieele East. Edition.

23.Zilva,T.F. Pannall, P.R. and Mayne,P.D.(1988)"Clinical chemistry in diagnosis and treatment" $5^{\text {th }}$ ed.,loyd-luke Publication,London.

24. Gaillen CM, Rlee,GW Mach CM Tomaselli T.N Nishiyasu and ER Nadel .plasma Volume expansion in humans after a single interse Exercise prohcol .J - Appl - physiol ,17; 1914 -1920 .1991.

25.Kei Nagashima, Gray W. cline, Gray W. Nack, Gerald I Shulmand and Ethhan R. Nadel . Intense exercise stimnlates albumin synthesis in the upright posture . J Appl .physiol . 88; 41-46,2000 .

26. Haskell, A ., E. Ballmer ,S .E. Anderson , J . Broom. P .J. Garlick , and M. A. McNurian .Transcapillary escape of albumin in humans during exercise-induced hypervolemia .J . appl Physiol 83: 407-413 .1997

27. Nagashima ,K.,A. Haskell , T. Nishiyasu , G W. Mack, and E. R . Nadel. The mechan ism for the postural specific plasma voiume increase after a single internse execise protocol .J. Appl . Physiol 86: 867-873 .1999 . 
28. Davis PC ,WP Bartoli , and J L Durstine . Effets of acnte Exercise intensily on plasma lipids and apolipoprotein, in trained Runners .J Appl . Physiol . 